\title{
Commentary
}

\section{The Paris Climate Agreement and the Three Largest Emitters: China, the United States, and the European Union}

\author{
Miranda A. Schreurs \\ Bavarian School of Public Policy, Technical University of Munich, 80333 Munich, Germany; \\ E-Mail: miranda.schreurs@hfp.tum.de
}

Submitted: 5 May 2016 | Accepted: 10 August 2016 | Published: 8 September 2016

\begin{abstract}
The Paris Agreement would not have come into being had China, the United States (US), and the European Union (EU), which together contribute more than half of all global greenhouse gas emissions, not signaled their intent to take major steps to reduce their domestic emissions. The EU has been at the forefront of global climate change measures for years having issued binding domestic emission reduction targets for 2020 and 2030. For many years, China refused to announce a target date for when it might begin reducing its greenhouse gas emissions, and the US Congress blocked action on climate change. In the lead up to the Paris climate negotiations, however, there were major shifts in China's and the US's climate positions. This commentary examines the climate policies of the three largest emitters and the factors motivating the positions they took in the Paris negotiations. Given that the commitments made in Paris are most likely insufficient to keep global temperature from rising $2{ }^{\circ} \mathrm{C}$ above pre-industrial levels, the commentary also considers what the likelihood is that these three major economies will strengthen their emission reduction targets in the near future.
\end{abstract}

\section{Keywords}

China; climate change; European Union; leadership; Paris; United States

\section{Issue}

This commentary is part of the issue "Climate Governance and the Paris Agreement", edited by Jon Hovi and Tora Skodvin (University of Oslo, Norway).

(C) 2016 by the author; licensee Cogitatio (Lisbon, Portugal). This article is licensed under a Creative Commons Attribution 4.0 International License (CC BY).

\section{Introduction}

The Paris Agreement marks the beginning of a new phase in international efforts to promote climate mitigation and adaptation. The agreement sets a goal of maintaining the global temperature rise to below $2{ }^{\circ} \mathrm{C}$ above pre-industrial levels, and to strive for no more than 1.5 ${ }^{\circ} \mathrm{C}$. As of August 1, 2016, 162 Intended Nationally Determined Contributions (INDCs) had been submitted to the United Nations Framework Convention on Climate Change (UNFCCC) Secretariat (UNFCCC Secretariat, 2016). As the countries of the European Union (EU) submit a joint INDC, this means that almost 200 countries have submitted pledges. Existing pledges do not, however, appear to go far enough to remain within the $2{ }^{\circ} \mathrm{C}$ target. An assessment made by an international team of experts and published in the journal Nature estimates that the existing INDCs would most likely only keep temperature rises at between $2.6^{\circ} \mathrm{C}$ and $3.1^{\circ} \mathrm{C}$ by 2100 (Rogelj et al., 2016).

Although the global nature of the agreement is its hallmark, it would not have come into being had the three largest greenhouse gas (GHG) emitters not signaled that they were prepared to take action. Combined, China (30 percent), the US (15 percent), and the EU (EU-28) (10 percent)-contribute more than half of all global greenhouse gas emissions (PBL Netherlands Environmental Assessment Agency, 2015).

Within a few weeks of each other between October and November 2014, the EU, the United States (US), and China each pledged to reduce their GHG emissions. Given the failure of previous attempts to forge a global 
agreement acceptable to all three of these major emitters, what led to their Paris commitments? Why were they able to find the politically feasible solutions (Underdal, 1998) which had escaped them during the negotiations in Copenhagen?

The Paris Agreement is both legally binding and voluntary. The agreement obliges all parties "to undertake and communicate ambitious efforts" and to have these efforts represent "a progression over time". It also expects each signatory to "prepare, communicate and maintain successive nationally determined contributions that it intends to achieve." Every five years a nationally determined contribution is to be communicated; a contribution may be adjusted "with a view to enhancing its level of ambition" (UNFCCC, 2015). Can such upward adjustments be expected from China, the EU, and the US? This question is quite critical as without a strengthening of the reduction commitments made by the three largest emitters, it is doubtful that other countries could be persuaded to go farther than they agreed to in Paris. Further action will be needed if there is to be a realistic chance of maintaining global average temperature increases to within the $2{ }^{\circ} \mathrm{C}$ target.

\section{The European Union}

Over the past two decades the EU has been the most consistent in not only calling for the establishment of binding international climate agreements but in backing these calls up with its own binding GHG emission reduction targets. It has exhibited a kind of unilateral leadership, "setting the pace for others to follow" (Underdal, 1994, p. 183). For the 1997 Kyoto Protocol, the EU committed to an 8 percent reduction in its GHG emissions compared with 1990 levels. A decade later, it committed to three goals to be met by 2020: a 20 percent reduction in GHG levels (compared to 1990 levels), obtaining 20 percent renewables in the energy consumption mix, and reducing energy consumption with a 20 percent improvement in energy efficiency (compared to projected levels) (European Commission, 2010).

In October 2014, the EU announced its 2030 targets: a binding 40 percent GHG emissions reduction target (relative to 1990 levels), a renewable energy target of 27 percent and a minimum energy efficiency improvement of 27 percent. Unlike in 2008 when the EU announced its 2020 target, no agreement has been reached on how responsibility for achieving these targets on a country-by-country basis is to be determined.

A variety of factors can explain why the EU has been at the forefront of global efforts to tackle climate change. One is the strong level of public concern with climate change. In a 2015 Eurobarometer poll, 91 percent of respondents found climate change to be a serious or very serious problem (European Commission, 2015). A second is strong concern about long-term en- ergy security. European supplies of fossil fuels are limited. The EU is the world's single largest energy importer; it imported over 53 percent of the energy it consumed in 2013 (Eurostat, 2015). This is a factor behind the establishment in 2015 of the Energy Union, an initiative to enhance coordination on energy policy among the EU Member States focusing on five policy areas: supply security, an integrated internal energy market, energy efficiency, climate change, and research and innovation for low carbon technologies.

Europe's relative share of global GHG emissions at the time of the Paris negotiations (10 percent) was considerably less than it was at the time of the Kyoto negotiations (15 percent). Exerting soft power by example (showing that a transition to a low carbon economy is possible), may be one of the best ways for Europe to continue to exert global leadership in this policy area as its relative international weight declines along with its declining emissions levels (Skodvin \& Andresen, 2006)? The transition is viewed by many as a way of developing a more sustainable economy, stimulating new industries and creating new jobs.

Still, there are many barriers to overcome for a successful energy transition. Path dependencies remain strong. The oil, coal, and gas industries exert considerable pressure on politicians. Environmental interests are also not equally strong across the EU. As renewables have grown in some parts of Europe, so too have efforts to block their progress especially in regions which feel threatened by their success.

There are different views about the best road ahead for Europe. When the EU 2030 emission targets were being negotiated, Germany was pushing for relatively ambitious climate targets. Poland resisted these efforts arguing that Europe was taking on too much of the global climate burden and that its coal-dominated economy would be threatened by the changes. Great Britain opposed the German push for a higher renewables target because of their ambitions to invest further in nuclear energy (Dehmer, 2014) although they did support Germany in calling for a more ambitious energy efficiency target. In the end, the EU settled on 4027-27 targets rather than higher targets wanted by the European Parliament and some more progressive member states.

There is also the added challenge of the resurgence of nationalist and far right parties. Populism in Europe has been driven by public frustration with economic inequalities, fears stemming from globalization, and reactions to immigrants entering the EU from Eastern Europe and conflict ridden and economically challenged regions in the Middle East and Africa. Marie Le Pen's National Front in France is now a political force to be reckoned with. The party is opposed to participation in the international climate agreement. David Cameron's political gamble to hold a referendum on membership in the EU ended badly. Brexit will mean 
the EU will lose one of its stronger supporters of climate action although British-EU cooperation on climate change is likely to continue in some form.

To date, no effort sharing agreements have been reached among the member states to determine what a fair allocation of burden should be towards meeting the EU's GHG and renewable energy targets. In this political environment, further strengthening of climate targets will be very difficult. EU leadership on climate in the future is likely to be more strongly dependent on developments in the US, China, and other emerging economies.

\section{The United States}

Although the William J. Clinton Administration signed the Kyoto Protocol in 1997, George W. Bush abandoned the agreement in 2001. Upon entering office in 2009, Barack Obama signaled his intentions to once again assume a US leadership role in the climate negotiations. Two interconnected strategies have been pursued. One has been gaining cooperation on action from China and India and the other has been targeting emissions from automobiles and power plants domestically.

Years of efforts to improve bilateral climate cooperation with China led to the joint press statement by China's President Xi Jinping and President Obama in November 2014 in which they announced their 2030 climate targets. Obama pledged that the US would cut its emissions by $26-28$ percent below 2005 levels by 2025, with a best effort to reduce by 28 percent. President Xi Jinping announced that China would peak its GHG emissions by around 2030 and if possible earlier, increase the non-fossil fuel share of energy to 20 percent, lower the carbon intensity of the GDP by 60 to 65 percent below 2005 levels by 2030 and expand forest coverage. This remarkable achievement, which helped to break a long standing deadlock in the international negotiations (Underdal, Hovi, Kallbekken, \& Skodvin, 2012), would not have been possible had both countries not shown that they were prepared to take serious steps to address their domestic GHG emissions.

In order to show climate progress, the Obama administration has had to find a way to work around Congressional opposition to climate action. It has done this through various executive actions. The Environmental Protection Agency (EPA) has mandated Federal Government facilities to cut their GHG emissions by 40 percent compared to 2008 levels by 2025 and to expand the use of electricity from renewable sources. The EPA has issued a series of new fuel efficiency standards for automobiles and light- and heavy- vehicles based on the US Clean Air Act. In 2013, the President's Climate Action Plan (2013) was announced (Executive Office of the President, 2013). The plan outlined measures to cut carbon pollution to make it possible to meet the "voluntary" pledge to cut emis- sions Obama made in Copenhagen (to reduce US GHG emissions by 17 percent of 2005 levels by 2025) and paved the path for the establishment of the Clean Power Plan. The Clean Power Plan is the single most important element of the Obama administration's climate strategy. It aims to cut $\mathrm{CO}_{2}$ emissions from power plants by 32 percent by 2030 (EPA, 2015a).

The Obama administration moreover worked to shape the Paris Agreement in such a way that it would not require ratification by the Senate. The Obama administration's position is that the legally binding aspects of the agreement are already covered by earlier agreements (like the UNFCCC) which the Senate has already ratified and thus, do not require renewed approval. The INDCs are non-binding, aspirational targets, and thus, as interpreted by the Obama administration, do not need Congressional approval.

While Obama's climate initiatives have been welcomed by environmentalists, they have been attacked by conservatives. Republican Senator James Inhofe, Chairman of the Senate Environment and Public Works Committee, well-known for his climate skepticism, has challenged the Obama administration's position stating in a press release: "Despite this administration's desperate effort to demonstrate an international agreement on climate change, the announcement of a final climate deal from Paris is no more significant to the US than the Kyoto Protocol announcement 18 years ago....This agreement is no more binding than any other 'agreement' from any Conference of the Parties over the last 21 years" (Inhofe, 2015). Republican Presidential candidate Donald Trump has vowed to pull the US out of the climate agreement if he is elected. In contrast, Democratic Presidential candidate Hillary Clinton has signaled her intentions to continue with and even strengthen US climate actions.

Beyond Obama's climate initiatives, it should be noted that some emissions reductions are due to changes in the fuel mix. The 2005 Energy Policy Act, a signature achievement of Vice President Dick Cheney, eased restrictions on fossil fuel extraction on federal lands. One consequence of the policy was that it eased permitting for unconventional oil and gas drilling, also known as fracking. Cheap oil and gas have led to a displacement of coal and a concomitant reduction in GHG emissions due to the lower carbon content of gas relative to coal. Thus, whereas US GHG emissions were rising through 2007, they have since declined quite dramatically. Emissions in 2013 were 5.9 percent higher than 1990 levels, far less than at their peak in 2007 when they were 17 percent higher (EPA, 2015b). These emission reductions should not, however, be considered sustainable as eventually, these natural gas reserves will be depleted.

The success of the Obama administration's climate initiatives and the potential to eventually strengthen the US GHG reduction target will depend heavily on the 
outcome of the 2016 presidential and Congressional elections and court rulings on Obama's use of executive orders.

\section{China}

In China's view, the main historical responsibility for rising GHG emissions lies with the US, Europe, Japan, and other rich countries. China has for many years resisted pleas by the international community for it to cap its rapidly rising emissions and has instead argued that developed countries have to do more to reduce their emissions and to assist developing countries financially and technologically with climate mitigation and adaptation.

In 2009 in Copenhagen, China announced that it was not prepared to take on an emissions reduction commitment, but it would reduce its energy intensity by 40 to 45 percent of 2005 levels by 2020, expand its use of non-fossil fuels to about 15 percent, and increase forest cover by 40 million hectares. China's announcement in the lead-up to the Paris negotiations that it was now prepared to peak its emissions around 2030 is thus a significant break with the past. What is behind China's change in position?

To an extent international pressure is a factor. China became the world's largest GHG emitter, surpassing US emission levels in 2006. This makes it increasingly difficult to shift exclusive blame for climate change to the West. It has also become more difficult to use per capita emission differentials to argue for exceptions for China. In 2012, per capita GHG emissions in China (7.1 tons) were still well below those in the US (16.4 tons) but they were basically the same as the EU average (7.4 tons) (PBL Netherlands Environmental Agency, 2013).

There is also a growing desire in China to be recognized as an international power. That China together with the US and the EU set the tone for the Paris negotiations has strong symbolic power.

Still more than international pressure, domestic factors have shaped China's changing stance on climate action. China is experiencing severe pollution problems and growing civil dissatisfaction with pollution levels. Air pollution has reached crisis levels largely because of the dramatic growth in automobiles, continued heavy reliance on coal (down from about 76 percent in 1990 but still at about 63 percent in 2013) and the growing demand for oil.

As is the case in the EU, China is concerned about long-term energy security having become a net energy importer. With a population that is not expected to peak until around 2025 at about 1.41 billion (Fu, 2015) and an economic growth rate that although slowing is still at between 6 and 7 percent per annum, China's appetite for energy will remain robust.

China thus has strong incentives to promote alternative sources of energy and energy efficiency. Government leaders also see considerable innovation po- tential linked to the greening of the economy and the development and export of green technologies and can use support of a green economy as an argument in favor of modernization and the shutting down of inefficient industries, which otherwise would be politically more challenging.

These various factors have contributed to China's leadership's decision to introduce a series of increasingly ambitious environmental laws and programs. In March 2014, Premier Li Keqang declared war against pollution. A program to reduce emissions from the top 10,000 largest carbon dioxide emitters was included in the $12^{\text {th }}$ Five Year Plan. China introduced seven pilot regional carbon emissions trading schemes and will launch its national carbon emissions trading scheme in 2017 (Chen \& Reklev, 2014). As of 2014, China was investing more in renewable energy than any other country in the world and also had the largest amount of installed capacity (Ren21, 2015). The $13^{\text {th }}$ Five Year Plan issued in early 2016 includes measures intended to help China implement its 2030 climate, energy efficiency, and fuel switching targets.

\section{Conclusion}

Assessments suggest that the INDCs which countries have proposed for the Paris Agreement do not add up to what it will take to maintain global temperature increases below $2{ }^{\circ} \mathrm{C}$. The political situation in the $\mathrm{EU}$ and the US will make it challenging but not impossible to strengthen their climate action commitments in the coming period. China may be best positioned to further strengthen its climate targets assuming that its political situation does not destabilize. That China announced it would cap its emissions by 2030 or earlier, suggests that the leadership may believe that an earlier peak is possible. If the population peaks in 2025, this too would increase the likelihood that emissions could begin to decline around this time, assuming energy efficiency improvements continue.

If China were to step up to take a stronger leadership role on climate and make an early announcement of plans to move up the date by when it plans to peak and then begin to reduce its GHG emissions, it would weaken the arguments of populists in the West that major transition countries are not doing their fair share.

At the same time, the EU and the US will have to work to convince skeptics of the benefits of early action. Frontrunners on both sides of the Atlantic have already done much to show the benefits that can be achieved from pursuing low carbon energy transitions.

\section{Acknowledgments}

This commentary has benefitted from the critiques of two anonymous reviewers as well as from Jon Hovi and Tora Skodvin. 


\section{Conflict of Interests}

The author declares no conflict of interests.

\section{References}

Chen, K., \& Reklev, S. (2014, August 31). China's national carbon market to start in 2016-Official. Reuters. Retrieved from http://www.reuters.com/article/2014/0 8/31/china-carbontrading-idUSL3NOR107420140831

Dehmer, D. (2014, October 22). Energiewende auf europäisch. Der Tagesspiegel. Retrieved from http:// www.tagesspiegel.de/wirtschaft/stromstreit-in-brue ssel-energiewende-auf-europaeisch/10870252.html

Environmental Protection Agency. (2015a, October 23). Carbon pollution emission guidelines for existing stationary sources: Electric utility generating units; final rule. Federal Register, 80(205), 64662-65120.

Environmental Protection Agency. (2015b, April 15). Inventory of US greenhouse gas emissions and sinks: 1990-2013. (EPA 430-R-15-004). Washington, DC: US Environmental Protection Agency.

European Commission. (2010, March 3). Communication from the commission. Europe 2020: A European strategy for smart, sustainable, and inclusive growth. Brussels: European Commission.

European Commission. (2015, May-June). Special Eurobarometer 435: Climate change. Retrieved from http://ec.europa.eu/clima/citizens/support/docs/rep ort_2015_en.pdf

Eurostat. (2015, May). Energy production and imports. Retrieved from http://ec.europa.eu/eurostat/statisti cs-explained/index.php/Energy_production_and_im ports

Executive Office of the President. (2013, June). The president's climate action plan. Washington, DC: US Government. Retrieved from https://www.whitehouse. gov/sites/default/files/image/president27sclimateac tionplan.pdf

Fu, J. (2015, October 7). Population to peak in 2025. China Daily. Retrieved from http://www.chinadaily.com. cn/china/2015-10/07/content_22119396.htm

Inhofe, J. (2015, December 12). Inhofe statement on final COP21 climate deal. Retrieved from http:// www.epw.senate.gov/public/index.cfm/2015/12/inh ofe-statement-on-final-cop21-climate-deal

PBL Netherlands Environmental Assessment Agency. (2013). Trends in global $\mathrm{CO}_{2}$ emissions: 2013 report. Hague: PBL Netherlands Environmental Assessment Agency. Retrieved from http://edgar.jrc.ec.europa. eu/news_docs/pbl-2013-trends-in-global-co2-emissi ons-2013-report-1148.pdf

PBL Netherlands Environmental Assessment Agency. (2015). Trends in global $\mathrm{CO}_{2}$ emissions: 2015 report. Hague: PBL Netherlands Environmental Assessment Agency. Retrieved from http://edgar.jrc.ec.europa. eu/news_docs/jrc-2015-trends-in-global-co2-emissi ons-2015-report-98184.pdf

REN21. (2013). Renewables 2013: Global status report. Paris: REN21 Secretariat. Retrieved from www.ren21. net/portals/0/documents/resources/gsr/2013/gsr20 13_lowres.pdf

Rogelj, J., den Elzen, M., Höhne, N., Fransen, T., Fekete, H., Harald Winkler, H., . . . Meinshausen, M. (2016, June 30). Paris agreement climate proposals need a boost to keep warming well below $2{ }^{\circ} \mathrm{C}$. Nature, 534 , 631-639.

Skodvin, T., \& Andresen, S. (2006). Part one: Negotiating international environmental regimes: Leadership revisited. Global Environmental Politics, 6(2), 13-27.

Underdal, A. (1994). Leadership theory: Rediscovering the arts of management. In I. W. Zartman (Ed.), International multilateral negotiation: Approaches to the management of complexity (pp. 178-197). San Francisco, CA: Jossey-Bass Publishers.

Underdal, A. (1998). Leadership in international environmental negotiations: Designing feasible solutions. In A. Underdal (Ed.), The politics of international environmental management (pp. 101-127). Amsterdam: Kluwer Academic Publishers.

Underdal, A., Hovi, J., Kallbekken, S., \& Skodvin, T. (2012). Can conditional commitments break the climate change negotiations deadlock? International Political Science Review, 33(4), 475-493.

UNFCCC. (2015, December 12). Paris agreement (FCCC/ CP2015/L.9/Rev.1, 12). Retrieved from https://un fccc.int/resource/docs/2015/cop21/eng/l09r01.pdf

UNFCCC Secretariat. (2016, August 7). INDCs. Retrieved from http://www4.unfccc.int/submissions/indc/Sub mission\%20Pages/submissions.aspx

\section{About the Author}

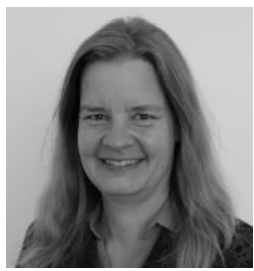

Miranda A. Schreurs is Professor of Environment and Climate Politics at the Bavarian School of Public Policy, Technical University of Munich. Prior to this she was Director of the Environmental Policy Research Center and Professor of Comparative Politics at the Freie Universität Berlin. Her research focuses on climate, energy, and environmental policy making in Asia, Europe, and the United States. She has served on numerous advisory bodies in China, Germany, and Europe. 